\title{
IN MEMORY OF RABBI SHEILA SHULMAN Z'L
}

I first got to know Sheila in 1982 when we were in a Jewish lesbian feminist group together. Curiously, without discussing it, we both decided to become rabbis, embarking on rabbinic training at Leo Baeck College in 1984.

Ordained in 1989, Sheila brought all of who she was as a lesbian, a radical feminist, a teacher and a writer to her rabbinate in every context. In 1990, together with a group of lesbian friends, Sheila founded Beit Klal Yisrael (BKY), the first synagogue to be a home for LGBT Jews in Britain.

In addition to nurturing and nourishing BKY, and creating there an environment where Jews on the margins could develop a sense of belonging and engage actively with Jewish teaching and practice, Sheila also made an invaluable contribution to the life of Finchley Reform Synagogue and was a beloved teacher at Leo Baeck College, where she taught Jewish thought. One of Sheila's greatest accomplishments as a rabbi was to mentor many individuals on their journeys into the rabbinate, inspiring several people to become rabbis over the years.

Sheila was a remarkable person. You can get a sense of her distinctive voice and vision by reading 'A Kind of Submerged Continent', a sermon she gave at BKY on Rosh Ha-Shanah morning, 1997. The sermon is included in Women Rabbis in the Pulpit: A Collection of Sermons, published in December 2015 to mark the fortieth anniversary of the ordination of Rabbi Dr Jackie Tabick, the first woman rabbi in Britain, and the eightieth anniversary of the ordination of Rabbi Regina Jonas, the first woman rabbi in the world (edited by Rabbi Dr Barbara Borts and Rabbi Elli Tikvah Sarah, Kulmus Publications through lulu.com).

Zichronah livrachah - May her memory be a source of blessing for all our lives.

Rabbi Elli Tikvah Sarah 